\title{
Green Synthesis (Using Plant Extracts) of Ag and Au Nanoparticles
}

\author{
Rais Ahmad* and Anam Mirza \\ Department of Applied Chemistry, Environmental Research Laboratory, Aligarh Muslim University, Aligarh, India
}

Submission: May 30, 2017; Published: June 22, 2017

*Corresponding author: Rais Ahmad, Faculty of Engineering and Technology, Environmental Research Laboratory, Department of Applied Chemistry, Aligarh Muslim University, Aligarh, India, Tel: 91- 571-2700920-23; Fax No: +91-0571-2400528; Email: rais45@rediffmail.com

\section{Abstract}

The green synthesis of nanoparticle is one step towards the essential need for sustainable and ecofriendly environment. This review paper presents the overview for the synthesis of $\mathrm{Ag}$ and $\mathrm{Au}$ nano particles using natural plant extracts. The synthesis of $\mathrm{Ag}$ and Au nanoparticles is an alarming and potential area of application research in nanotechnology. We have provided an overview of various reports by various researchers for the green synthesis (using extracts of leaves, fruits, flowers etc.) of $\mathrm{Ag}$ and $\mathrm{Au}$ nanoparticles.

Keywords: Green synthesis; Nanoparticles; Ag and Au

\section{Introduction}

The prefix 'nano' indicates one billionth or $10^{-9}$ units [1]. In other words, nanoparticles can be defined as the clusters of atoms in the size range of $1-100 \mathrm{~nm}$ [2]. The nanoparticles show unique physical, chemical and biological properties due to their high surface-to-volume ratio [3].

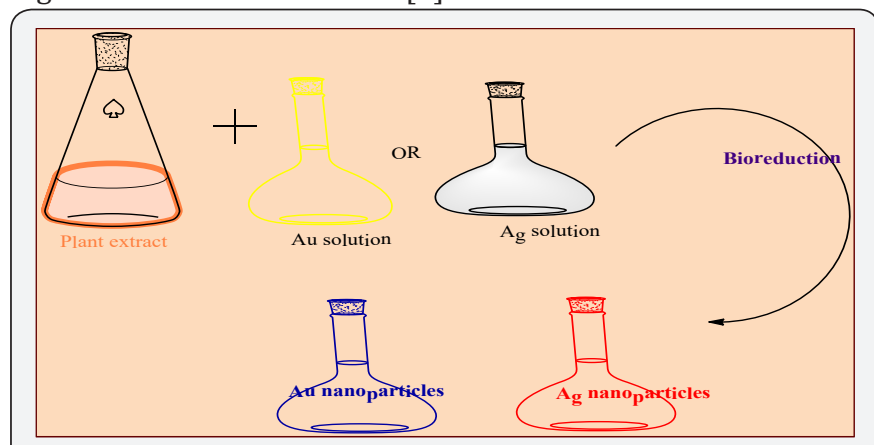

Figure 1: Synthesis of $\mathrm{Ag}$ and Au nanoparticles.

The integration of green chemistry to nanotechnology is one of the most alarming and explored area for the nanoscience researcher. The towering environmental issues had attracted the researchers towards the novel green synthesis of nanoparticles in biological systems such as bacteria, fungi and plants [3]. However, exploration of the plant extracts as the medium of synthesis has heightened interest due to its simplicity, easiness and viable approach and also, the use of plant extracts for the synthesis of nanoparticles does not require elaborate processes $[3,4]$. Plant extracts acts as a natural reducing and stabilizing agent at ambient condition (Figure 1). Various nanoparticles such as $\mathrm{Ag}, \mathrm{Au}$, Pt and $\mathrm{Pd}$ have been synthesized via various green synthesis by many researchers [4,5].

Among the various nanoparticles, Ag and Au nanoparticles are especially attractive owing to their easy preparation, large specific surface area, good biocompatibility and high antimicrobial activity. Ag and $\mathrm{Au}$ nanoparticles play a significant role in the field of biology, medicine etc., and due to its attractive physicochemical properties [5]. Ag and Au nanoparticles find potential applications in the treatment of cancer hyperthermia, in electronics, catalysis, bio-labelling, biosensors devices for the detection of viruses and bacteria, drug delivery, tissue/ tumor imaging, photo thermal therapy etc., [4,5]. In daily life, nanoparticles of $\mathrm{Ag}$ and $\mathrm{Au}$ are widely used in shampoos, soaps, detergents, shoes, cosmetic products and toothpaste.

\section{Discussion}

$\mathrm{Ag}$ and $\mathrm{Au}$ nanoparticles have been synthesized by various researchers using plant extracts. Some of the key studies have been reported here. Synthesis of highly stable Ag nanoparticles by the extract of geranium leaves (Pelargonium graveolens) has been reported [6]. The seed extract of Jatrophacurcas was 


\section{Global Journal of Nanomedicine}

utilized for the synthesis of Ag nanoparticles [7]. Another research revealed the synthesis of $\mathrm{Ag}$ and $\mathrm{Au}$ nanoparticles using a leaf extract of Phyllanthusamarus and Black tea leaf extract, respectively [4,5]. Another study reported the synthesis of gold nanoparticles by lemon grass (Cymbopogonflexuosus) plant extract [1]. The biosynthesized Ag nanoparticles using Acalypha indica leaves extract was also reported [3]. Another study revealed the production of gold and silver nanoparticles in aqueous solution at ambient conditions using green tea (Camellia sinensis) extract as reducing and stabilizing agent [8]

Another synthesis of $\mathrm{Au}$ nanoparticles was reported using leaf extract of antidiabetic potent Cassia auriculata and $\mathrm{Ag}$ nanoparticles by aqueous leaf extract of Catharanthusroseus, respectively $[9,10]$. Synthesis of gold nanoparticles was reported using leaf extract of Magnolia Kobus [11]. Synthesis of silver nanoparticles using Terminaliachebula fruit extract [12]. Synthesis of silver nanoparticles was reported by Morusnigra leaf extract [13]. Synthesis of silver nanoparticles was reported from the leaf extract of Azhadirachtaindica [14]. Gold nanoparticles was synthesized using Solanuslycopersicum (Tomato) aqueous extract [15]. Another study was reported for the synthesis of silver nanoparticles using fresh tomato pomace extract [16]. The Ag nanoparticles was produced from peel extract of Tangerine [17].

\section{Conclusion}

There has been growing interest in ecofriendly green synthesis of nanoparticles. Nanoparticles such as Ag and Au finds enormous application in almost every field such as in the areas of chemistry, electronics, medicine and daily products etc. Hence, the green synthesis of nanoparticles using various plant extracts appears to be the cost effective and simple alternative for the synthesis of Ag and Au nanoparticles.

\section{References}

1. Kaushik N, Thakka MS, Snehit S, Mhatre MS, Rasesh Y, et al. (2010) Biological synthesis of metallic nanoparticles. Nanomedicine 6(2): 257-262.

2. Kholoud MMA, Ala'a E, Abdulrhman A, Reda AAA (2010) Synthesis and applications of silver nanoparticles. Arab J Chem 3(3): 135-140.

3. Krishnaraj C, Jagan EG, Rajasekar S, Selvakumar P, Kalaichelvan PT, et al. (2010) Synthesis of silver nanoparticles using Acylyphaindica leaf extracts and its antibacterial activity against water borne pathogens. Colloids Surf B Biointerfaces 76(1): 50-56.
4. Annamalai A, Sarah TB, Niji AJ, Sudha D, Christina VL (2011) Biosynthesis and characterization of silver and gold nanoparticles using aqueous leaf extraction of Phyllanthus amarus. Shum \& Thonn World Appl Sci J 13(8): 1833-1840.

5. Naznin AB, Samiran M, Saswati B, Rajibul AL, Debabrata M (2009) Biogenic synthesis of $\mathrm{Au}$ and $\mathrm{Ag}$ nanoparticles using aqueous solutions of Black Tea leaf extracts. Colloids Surf B Biointerf 71(1): 113-118.

6. Shankar SS, Ahmad A, Sastry M (2003) Geranium leaf assisted biosynthesis of silver nanoparticles. Biotechnol Prog 19(6): 16271631.

7. Harekrishna B, Dipak KB, Gobinda PS, Priyanka S, Santanu P, et al. (2009) Green synthesis of silver nanoparticles using seed extract of Jatrophacurcas. Colloids Surf A. Physicochem Eng Asp 348: 212-216.

8. Kannan BN, Natarajan S (2011) Green synthesis of biogenic metal nanoparticles by terrestrial and aquatic phototrophic and heterotrophic eukaryotes and biocompatible agents. Adv Colloid Interface Sci 169(2): 59-79.

9. Kumar VG, Gokavarapu SD, Rajeswari A, Dhas ST, Karthick V, et al (2011) Facile green synthesis of gold nanoparticles using leaf extract of antidiabetic potent Cassia auriculata. Colloids Surf B: Biointerf 87(1): $159-163$

10. Mukunthan KS, Elumalai EK, Trupti NP, V Ramachandra M (2011) Catharanthusroseus: a natural source for the synthesis of silver nanoparticles. Asian Pacific J Trop Biomed 1(4): 270-274.

11. Ying L, Tzu-Ying W, Shen-Ming C, M Ajmal A, Fahad MAAH (2012) Green synthesis and electrochemical characterizations of gold nanoparticles using leaf extract of Magnolia Kobus. Int J Electrochem Sci 7(2012): 12742-12751.

12. Edison TJI, Sethuraman MG (2012) Instant green synthesis of silver nanoparticles using Terminaliachebula fruit extract and evaluation of their catalytic activity on reduction of methylene blue. Process Biochem 47: 1351-1357.

13. Anu K, Kuldeep K, Sarika S (2013) Synthesis, characterization and antibacterial potential of silver nanoparticles by Morusnigra leaf extract. Indian J Pharm Biol Res 1(4): 16-24.

14. Lalitha A, Subbaiya R, Ponmurugan P (2013) Green synthesis of silver nanoparticles from leaf extract Azhadirachtaindica and to study its anti-bacterial and antioxidant property. Int J Curr Microbiol App Sci 2(6): 228-235.

15. Monalisa P, PL Nayak (2014) Green synthesis of gold nanoparticles using SolanusLycopersicum (TOMATO) aqueous extract. World J Nano Sci Technol 3(2): 74-80.

16. Josephine NM, B Radhika, T Ganesan (2014) Synthesis of silver nanoparticle using fresh tomato pomace extract. Int J Nanomat Biostruc 4(1): 12-15.

17. Eman A (2015) Eco-friendly production of silver nanoparticles from peel of Tangerine for degradation of dye. World J Nano Sci Eng 5(1): $10-16$.

\begin{tabular}{l} 
Your next submission with JuniperPublishers \\
will reach you the below assets \\
- Quality Editorial service \\
- Swift Peer Review \\
- Reprints availability \\
- E-prints Service \\
- Manuscript Podcast for convenient understanding \\
- Global attainment for your research \\
- Manuscript accessibility in different formats \\
( Pdf, E-pub, Full Text, Audio) \\
- Unceasing customer service \\
Track the below URL for one-step submission \\
https://juniperpublishers.com/submit-manuscript.php \\
\hline
\end{tabular}

